\title{
Data on nesting, incubation, and hatchling emergence in the two native aquatic turtle species (Emys orbicularis and Mauremys leprosa) from Doñana National Park
}

\author{
Carmen Díaz-Paniagua*, Ana Cristina Andreu, Adolfo Marco, Marta Nuez, \\ Judith Hidalgo-Vila, Natividad Perez-Santigosa \\ Estación Biológica de Doñana-CSIC, Sevilla, Spain. \\ * Correspondence: Estación Biológica de Doñana-CSIC, Avda. Américo Vespucio s/n, 41092 Sevilla, Spain. Phone: +34
954232340, Fax +34 954621125 , E-mail: poli@ebd.csic.es
} Received: 18 June 2013; received in revised form: 2 October 2013; accepted: 4 October 2013.

We monitored reproductive females of Emys orbicularis and Mauremys leprosa during the summer of 2001 in Doñana National Park. Radiographs revealed that females of both species may lay at least two clutches from May to July. We recorded incubation temperatures in one nest of each species, and found them to be $24.7^{\circ} \mathrm{C}$ in E. orbicularis and $28.7^{\circ} \mathrm{C}$ in M. leprosa. Egg incubation lasted 83 days in E. orbicularis, with all the hatchlings remaining in the nest until we extracted them in October, and 46-53 days in M. leprosa, with three hatchlings emerging one to 12 days after hatching, and three hatchlings remaining in the nest. We detected M. leprosa hatchlings in their first trip to the pond from late August to early October and E. orbicularis hatchlings from September $18^{\text {th }}$ to September $23^{\text {rd }}$.

Key words: aquatic turtles; incubation; nests; reproduction.

Nidos, incubación y emergencia de crías en las dos especies de quelonios acuáticos (Emys orbicularis y Mauremys leprosa) del Parque Nacional de Dońana. Durante el verano de 2001, se hizo un seguimiento intensivo de hembras grávidas de Emys orbicularis y Mauremys leprosa en Doñana. Mediante radiografías se detectó que ambas especies podían poner al menos dos puestas entre mayo y julio. Se obtuvieron datos sobre la temperatura de un nido de E. orbicularis (temperatura media de incubación $=24,7^{\circ} \mathrm{C}$ ) y de otro de $M$. leprosa (Temperatura media de incubación $=28.7^{\circ} \mathrm{C}$ ). El periodo de incubación de los huevos fue de 83 días en E. orbicularis, manteniéndose las crías dentro del nido tras la eclosión de los huevos hasta que fueron extraídas en octubre. En $M$. leprosa, la incubación duró entre 46 y 53 días; tres crías emergieron del nido entre uno y 12 días tras la eclosión, y otras tres permanecieron en el interior hasta que fueron extraídas. Además, se detectaron crías de $M$. leprosa recién nacidas en sus primeros viajes al medio acuático tras la eclosión entre finales de agosto y primeros de octubre, y de E. orbicularis entre el 18 y el 23 de septiembre.

Key words: incubación; nidos; quelonios acuáticos; reproducción.

The European pond turtle (Emys orbicularis) and the Mediterranean pond turtle (Mauremys leprosa) are two autochthonous aquatic turtle species found in the Iberian Peninsula. Currently, the conservation status of the populations of both species in Spain is considered to be vulnerable (Pleguezuelos et al., 2002). Information on the reproductive biology of these species is generally sparse, although KELLER (1997) determined their female breeding frequency and clutch size in Doñana National Park (DNP, Huelva, southwest Spain). Referring only to $M$. leprosa, Combescot (1955) described the gonadal 
cycle and Andreu \& Villamor (1989) ascertained the timing of main reproductive events. In this study we intensively monitored gravid females of both species in DNP, with the aim of locating their nests and obtaining information about their incubation and hatchling emergence periods.

From May 18th to June 1st of 2001, five E. orbicularis females and $10 \mathrm{M}$. leprosa females were captured from a pond in DNP. On the day of capture, each female was $\mathrm{x}$-rayed (radiation parameters: $65 \mathrm{~mA}, 75 \mathrm{~kW}, 0.5 \mathrm{~s}$ ) in order to detect eggs in her oviducts and subsequently returned to the pond. The pond was sampled a second time between June $10^{\text {th }}$ and $19^{\text {th; }}$ seven E. orbicularis and nine M. leprosa females were captured, $\mathrm{x}$-rayed, and released. Of these females, five and seven individuals of each species, respectively, had been $\mathrm{x}$-rayed during the first sampling.
From June $10^{\text {th }}$ to July $26^{\text {th }}$, we radiotracked (Biotrack 10 TW-3 single-celled tag radiotransmitters, Wareham, Dorsett, UK) four E. orbicularis and two M. leprosa gravid females in order to locate their nests. Their location was determined daily from 7:00 to 0:00 $\mathrm{h}$ at intervals of approximately three hours. This monitoring was complemented with the observation of movements of nontagged turtles around the pond. In addition, we conducted during this period intensive nest searches around several ponds. We signalled nests and measured and weighed their eggs with great care. For observation of the eggs, we placed a vertically-oriented glass window in one side of each nest. From mid-August onwards, the nests were monitored daily in order to record hatching and emergence dates, as well as body length and mass of emerged hatchlings. This methodo-

Table 1: Carapace length, body mass and number of shelled eggs ( $\mathrm{N}$ eggs) detected in seven $\mathrm{x}$-rayed females of Emys orbicularis and 13 x-rayed females of Mauremys leprosa.

\begin{tabular}{|c|c|c|c|c|c|c|c|c|c|}
\hline \multicolumn{5}{|c|}{ Emys orbicularis } & \multicolumn{5}{|c|}{ Mauremys leprosa } \\
\hline \multirow[t]{2}{*}{ Id } & \multirow{2}{*}{$\begin{array}{c}\text { Carapace } \\
\text { length }(\mathrm{mm})\end{array}$} & \multirow{2}{*}{$\begin{array}{c}\text { Body } \\
\text { mass (g) }\end{array}$} & \multicolumn{2}{|c|}{ N eggs (X-ray date) } & \multirow[t]{2}{*}{ Id } & \multirow{2}{*}{$\begin{array}{c}\text { Carapace } \\
\text { length }(\mathrm{mm})\end{array}$} & \multirow{2}{*}{$\begin{array}{c}\text { Body } \\
\text { mass (g) }\end{array}$} & \multicolumn{2}{|c|}{$\mathrm{N}$ eggs (X-ray date) } \\
\hline & & & May 14th & June 10th & & & & May $13^{\text {th }}$-June $1^{\text {st }}$ & June $10^{\mathrm{h}}-19^{\mathrm{th}}$ \\
\hline 1 & 151.9 & 680 & 8 & 6 & 1 & 205.3 & 1120 & 9 & 4 \\
\hline 2 & 138.7 & 508 & 7 & 6 & 2 & 149.9 & 505 & 0 & \\
\hline 3 & 146.1 & 637 & 6 & 8 & 3 & 173.8 & 1161 & 9 & \\
\hline 4 & 137.9 & 560 & 7 & 6 & 4 & 194.2 & 1031 & 9 & \\
\hline 5 & 146.9 & 624 & 0 & 0 & 5 & 178.9 & 796 & 0 & 0 \\
\hline 6 & 154.5 & 693 & & 5 & 6 & 185.9 & 868 & 7 & 0 \\
\hline \multirow[t]{7}{*}{7} & 150.9 & 685 & & 8 & 7 & 193.2 & 981 & 7 & 6 \\
\hline & & & & & 8 & 173.6 & 705 & 0 & \\
\hline & & & & & 9 & 205.3 & 1274 & 0 & 0 \\
\hline & & & & & 10 & 173.6 & 705 & 0 & 0 \\
\hline & & & & & 11 & 188.0 & 761 & & 4 \\
\hline & & & & & 12 & 196.8 & 985 & & 6 \\
\hline & & & & & 13 & 187.9 & 826 & & 0 \\
\hline \multicolumn{3}{|c|}{$\%$ of egg-bearing females } & 83.3 & 85.7 & \multicolumn{3}{|c|}{$\%$ of egg-bearing females } & 50.0 & 40.0 \\
\hline \multicolumn{3}{|c|}{ Mean number of eggs per clutch } & 7.0 & 6.5 & \multicolumn{3}{|c|}{ Mean number of eggs per clutch } & 8.2 & 5.0 \\
\hline
\end{tabular}


logy had been successfully used in nests of Testudo graeca (DíAz-PANiAgua et al., 1997). We placed a temperature data logger (Tidbit, HOBO, Onset Computer Corporation, Bourne, Massachusetts, USA) within each nest alongside the eggs to record nest temperature every $30 \mathrm{~min}$ during the incubation period. On October $18^{\text {th }}$, after a considerable decrease in ambient temperature, when we considered that embryo development had probably been completed, the remaining eggs and hatchlings were collected from the nests.

From August onwards, we erected a fence with $30 \mathrm{~cm}$ of height and $100 \mathrm{~m}$ of length along the entrance to the pond where females were collected in order to intercept hatchlings making their first trip to the pond after emergence. Several pitfall traps were set up along the fence, being checked daily until October.

Results of radiographs to detect gravid females are shown in Table 1. We observed gravid females of both species in May and in June samplings. We detected females with second clutches in both species.

We did not see radiotracked females digging nests. We observed only one E. orbicularis female digging a nest and laying eggs on July $7^{\text {th }}$ at 19:30. The nest was close to the pond (Table 2), in an area of wet, compact sand with a thick cover of helophytes. It contained eight eggs, two of which were found broken, and only four of the remaining eggs hatched.

Table 2: Main characteristics of Emys orbicularis and Mauremys leprosa nests monitored in Doñana National Park.

\begin{tabular}{lcc}
\hline \hline & E. orbicularis & M. leprosa \\
\hline Clutch date & July $7^{\text {th }}$ & July $15^{\text {th }}-22^{\text {nd }}$ \\
Number of eggs & 8 & 8 \\
Distance to the shore $(\mathrm{m})$ & 8 & 25 \\
Vegetation cover & thick & sparse \\
Nest width $(\mathrm{cm})$ & $7.5 \times 7.5$ & $18 \times 14$ \\
Nest depth $(\mathrm{mm})$ & $40-68$ & $90-155$ \\
Mean $( \pm$ SD; range) egg length $(\mathrm{mm})$ & $31.8( \pm 0.80 ; 30.5-33.0)$ & $33.7( \pm 1.17 ; 32.0-35.0)$ \\
Mean $( \pm$ SD; range) egg width $(\mathrm{mm})$ & $22.2( \pm 3.72 ; 20.5-31.4)$ & $20.7( \pm 0.47 ; 20.1-20.5)$ \\
Mean $( \pm$ SD; range) egg mass $(\mathrm{g})$ & $8.34( \pm 0.27 ; 7.9-8.7)$ & $8.43( \pm 0.51 ; 7.9-9.3)$ \\
Mean $( \pm$ SD) body mass of hatchlings $(\mathrm{g})$ & $4.75( \pm 0.44)$ & $4.55( \pm 1.43)$ \\
Mean $( \pm$ SD) carapace length of hatchlings $(\mathrm{mm})$ & $26.15( \pm 0.73)$ & $27.8( \pm 0.64)$ \\
Mean $( \pm$ SD) plastron length of hatchlings $(\mathrm{mm})$ & $22.28( \pm 0.43)$ & $23.5( \pm 1.25)$ \\
Hatching date & September $27^{\text {th }}-\mathrm{October} 6^{\text {th }}$ & September $6^{\text {th }}-18^{\text {th }}$ \\
Hatching rate & $50 \%$ & $62.5 \%$ \\
Nest emergence date & Not detected & September $17^{\text {th }}$ onwards \\
Incubation duration $($ days $)$ & 83 & $46-53$ \\
Mean nest temperature in August $\left({ }^{\circ} \mathrm{C}\right)$ & 25.38 & 29.28 \\
Mean minimum nest temperature in August $\left({ }^{\circ} \mathrm{C}\right)$ & 23.69 & 27.12 \\
Mean maximum nest temperature in August $\left({ }^{\circ} \mathrm{C}\right)$ & 27.65 & 32.27 \\
Mean nest temperature until hatching $\left({ }^{\circ} \mathrm{C}\right)$ & 24.67 & 28.65 \\
Mean minimum temperature until hatching $\left({ }^{\circ} \mathrm{C}\right)$ & 21.07 & 24.44 \\
Mean maximum temperature until hatching $\left({ }^{\circ} \mathrm{C}\right)$ & 27.65 & 32.27 \\
\hline
\end{tabular}

${ }^{a}$ From soil surface to the bottom of the nest. 


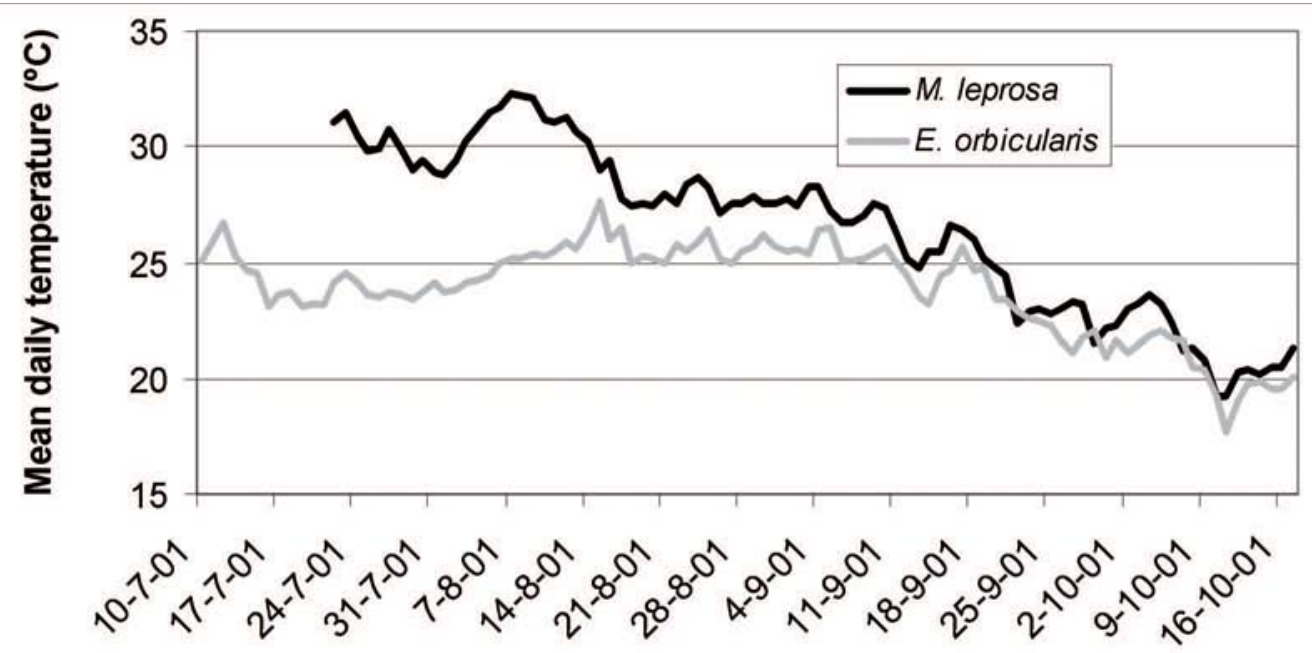

Figure 1: Variation in mean daily temperature during the incubation period in Emys orbicularis and Mauremys leprosa nests monitored in Doñana National Park.

From June $5^{\text {th }}$ to July $25^{\text {th }}$, we found in the meadows surrounding the pond a total of $70 \mathrm{M}$. leprosa nests that had been preyed upon, probably by rats according to the pattern of eggshell breakage and the tracks found around the nests. While we were excavating some of the predated nests, we identified three $M$. leprosa nests whose nesting date was estimated to be after July $15^{\text {th }}$. One of them, found on July $27^{\text {th }}$, contained eight eggs and was intact, while the other two, found on July $26^{\text {th }}$ and $27^{\text {th }}$, had been partially preyed upon and contained, respectively, two and one intact eggs. These nests were located at 20 to $25 \mathrm{~m}$ from the shore of the pond, in open areas characterized by sparse grass vegetation and low substrate moisture. Only eggs in the non-predated nest hatched, so we used only this nest for further analyses on hatching and emergence of $M$. leprosa (Table 2); one of the eggs in this nest was found broken, while six of the remaining ones hatched.
The size and mass of the eggs, as well as the data on hatching and hatchling emergence are shown in Table 2. The eggs of $M$. leprosa hatched earlier and had shorter incubation periods than those of E. orbicularis. The variation in mean daily incubation temperature is shown in Fig. 1. Incubation temperature was higher in the $M$. leprosa nest than in the E. orbicularis nest (Table 2).

Hatchling main biometric parameters are shown in Table 2 . In addition to obtaining emergence data from the monitored nests, we also intercepted, using the fence, four E. orbicularis and five $M$. leprosa hatchlings, as well as three other newborn $M$. leprosa hatchlings near other ponds (Fig. 2). We intercepted the first M. leprosa hatchlings travelling to the pond in late August and the last one on October $6^{\text {th }}$. Emys orbicularis hatchlings were intercepted between September $18^{\text {th }}$ and September $23^{\text {rd }}$. In the E. orbicularis nest, all the hatchlings remained in the nest, 


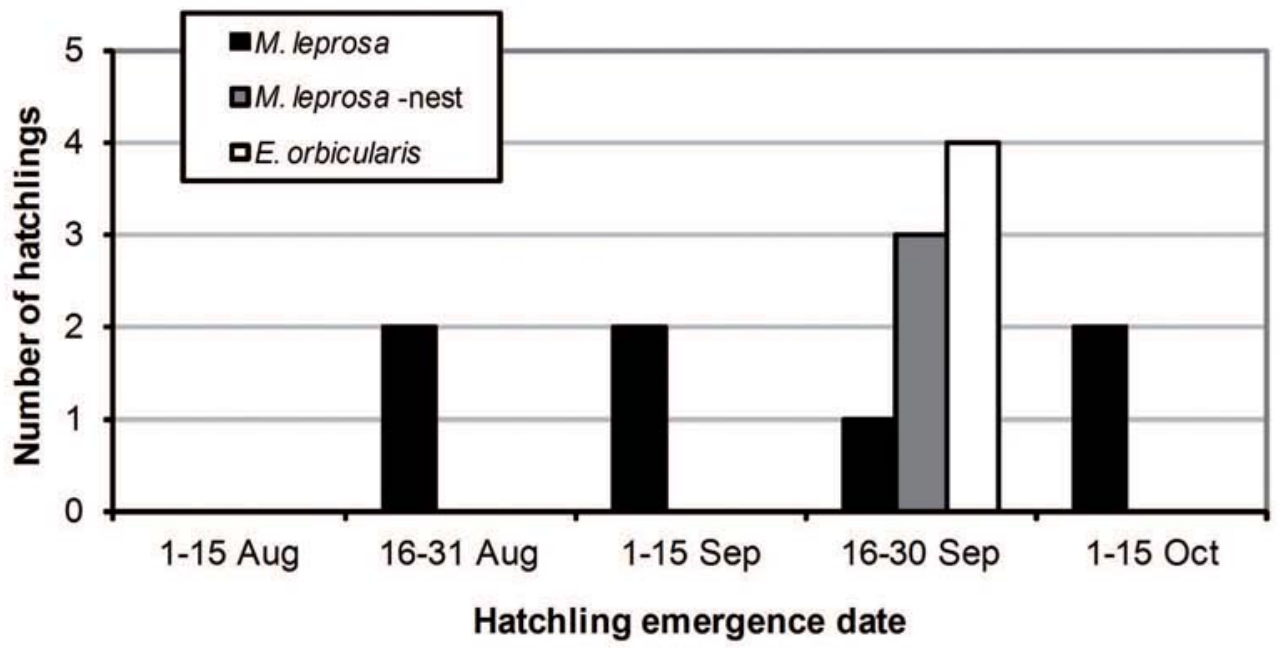

Figure 2: Number of Mauremys leprosa and Emys orbicularis hatchlings intercepted as they traveled to the pond after emerging from their nests. Dates of hatchling emergence in the monitored M. leprosa nest are also included. In E. orbicularis, no hatchlings emerged from the monitored nest.

meaning that their emergence was delayed at least one month relative to their hatching. In the $M$. leprosa nest, two hatchlings emerged the day after they hatched, another one 12 days later, and the remaining three did not emerge, meaning that their emergence was delayed longer than one month.

Emys orbicularis and $M$. leprosa have similar breeding habitats and periods in DNP, although $M$. leprosa is much more abundant (KELlER et al., 1995). Second clutches were detected in females of both species, being more frequent in E. orbicularis, as found in a previous study (ROQUES et al., 2006). In Doñana, only one $M$. leprosa female had been observed to have a second clutch (ANDREU \& VILLAMOR, 1989), even though a large number of females have been intensively monitored (Keller, 1997). However, Perez et al. (1979) suggested that females could be capable of developing up to three clutches per year, based on an inspection of ovarian follicles. Laying multiple clutches per year is a common reproductive strategy in chelonian species as it increases the reproductive output of females (WILBUR \& MORIN, 1988). In E. orbicularis, females can develop second clutches by fertilizing eggs with stored sperm, and clutches may exhibit multiple paternity (RoQUES et al., 2006).

In this study, radiotracking of gravid females was not adequate for nest detection, probably because females interrupted their nest travel when they observed us in the surroundings of the pond. Our results should be interpreted cautiously, as they come from only one monitored nest of each species.

We found pronounced differences in incubation temperature and duration between both species. The higher mean temperature detected in the $M$. leprosa nest was probably related to its location, considerably 
more exposed to ambient temperature fluctuations and drier than the location of the E. orbicularis nest. This type of exposure was also observed for nests destroyed by predators, which were located 10-200 m away from the pond, in a wide open area of grassland. At lower incubation temperatures, embryo development is slower and thus the incubation period is longer (PACKARD \& PACKard, 1988; DeEming \& Ferguson, 1991). For $M$. leprosa, we found a notable proportion of hatchlings emerging at the end of the summer; these hatchlings probably came from eggs of earlier clutches. On the other hand, in the nest of E. orbicularis, the lower incubation temperature, and the consequent slower development, probably resulted in hatching taking place on later, colder dates, which in turn could have delayed hatchling emergence. A delay in emergence is common in chelonians, and hatchlings may stay in the nest after hatching for short and variable periods (e.g. DíAZPANIAGUA et al., 1997) or even overwinter in the nest (GibBOns \& Nelson, 1978; Congdon \& GibBOns, 1985; JACKSON, 1994; DEPARI, 1996). The two nests monitored in this study contained late clutches, while the first hatchlings intercepted in August might have come from early clutches. Because newborn hatchlings of both species have been commonly observed in the spring in different localities (Mauremys leprosa: HeRnÁNDEZ GIL et al., 1993; ARAUjO et al., 1997. Emys orbicularis: SERVAN, 1983; SEgurado et al., 2005), it is possible that the hatchlings extracted from our monitored nests, especially those in the E. orbicularis one, could have started overwintering in the nest.

\section{Acknowledgement}

This study was funded by Junta de Andalucía (Grupo de Investigación RNM 128) and Ministerio de Agricultura y Medio Ambiente-OAPN (proyecto 158/2010).

\section{REFERENCES}

Andreu, A.C. \& Villamor, M.C. (1989). Calendario reproductivo y tamaño de puesta en el galápago leproso, Mauremys leprosa (Schweigger, 1812) en Doñana, Huelva. Doñana Acta Vertebrata 16: 167-172.

Araújo, P.; Segurado, P. \& Santos, N. (1997). Bases para a Conservação das Tartarugas de Água Doce, Emys orbicularis e Mauremys leprosa. Series: Estudos de Biologia e Conservação da Natureza, vol. 24. Instituto de Conservação da Natureza. Lisboa, Portugal.

Combescot, C. (1955). Sexualité et cycle génital de la tortue d'eau algérienne, Emys leprosa Schw. Bulletin de la Société d'Histoire Naturelle de l'Afrique du Nord 45: 366-377.

Congdon, J.D. \& GibBons, J.W. (1985).

Egg components and reproductive characteristics of turtles: Relationships to body size. Herpetologica 41: 194-205.

DeEming, D.C. \& Ferguson, M.W.J. (1991). Physiological effects of incubation temperature on embryonic development in reptiles and birds, In D.C. Deeming \& M.W.J. Ferguson (eds.) Egg Incubation. Its Effects on Embryonic Development in Birds and Reptiles. Cambridge University Press, Cambridge, UK, pp. 147-172.

DePARI, J.A. (1996) Overwintering in the nest chamber by hatchling painted turtles, Chrysemys picta, in northern New Jersey. Chelonian Conservation and Biology 2: 5-12. 
Díaz-Paniagua, C.; Keller, C. \& Andreu, A.C. (1997). Hatching success, delay of emergence and hatchling biometry of the spur-thighed toroise, Testudo graeca, in south-western Spain. Journal of Zoology 243: 543-553.

Gibbons, J.W. \& Nelson, D.H. (1978). The evolutionary significance of delayed emergence from the nest by hatchling turtles. Evolution 32: 297-303.

Hernández Gil, V.; Dicenta LópezHiguera, F.; Robledano Aymerich, F.; García Martínez, M.L.; Esteve Selma, M.A. \& RAMírez DíAZ, L. (1993). Anfibios y Reptiles de la Región de Murcia. Universidad de Murcia, Murcia, Spain.

JACKSON, D.R. (1994). Overwintering of hatching turtles in northern Florida. Journal of Herpetology 28: 401-402.

Keller, C. (1997). Ecología de Poblaciones de Mauremys leprosa $y$ Emys orbicularis en el Parque Nacional de Doñana. Ph.D. dissertation, Universidad de Sevilla, Sevilla, Spain. Keller, C.; Díaz-Paniagua, C.; Andreu, A.C. \& Bravo, M.A. (1995). Distribution of freshwater turtles in the Doñana National Park (SW Spain). Implications for the management of an isolated population, In International Congress of Chelonian Conservation:France, Gonfaron, Tortoise Village, $6^{\text {th }}$ to $10^{\text {th }}$ of July 1995: Proceedings. SOPTOM, Gonfaron, France, pp. 192-195.

PACKard, G.C. \& PACKard, M.J. (1988) The physiological ecology of reptilian eggs and embryos, In C. Gans \& R.B. Huey (eds.) Defense and Life History. Series: Biology of the Reptilia, vol. 16 Ecology B. Alan R. Liss, New York, USA, pp. 523-605.

Perez, M.; Collado, E. \& Ramo, C. (1979). Crecimiento de Mauremys caspica leprosa (Schweigger, 1812) (Reptilia, Testudines) en la Reserva Biológica de Doñana. Doñana Acta Vertebrata 6: 161-178.

Pleguezuelos, J.M.; Márquez, R. \& Lizana, M. (2002): Atlas y Libro Rojo de los Anfibios y Reptiles de España. Dirección General de la Conservación de la Naturaleza - Asociación Herpetológica Española, Madrid, Spain.

Roques, S.; Díaz-Paniagua, C.; Portheault, A.; Pérez-Santigosa, N. \& HidalgoVILA, J. (2006). Sperm storage and low incidence of multiple paternity in the European pond turtle, Emys orbicularis: a secure but costly strategy? Biological Conservation 129: 236-243.

Segurado, P.; Ayres Fernández, C. \& Cordero Rivera, A. (2005). La cistude d'Europe dans la Péninsule ibérique. Manouria 8: 19-20.

SERVAN, J. (1983). Émergence printanière des jeunes Cistudes en Brenne. Bulletin de la Société Herpétologique de France 28: 35-37.

WiLbur, H.M. \& MORIN, P.J. (1988). Life history evolution in turtles, In C. Gans \& R.B. Huey (eds.) Defense and Life History. Series: Biology of the Reptilia, vol. 16 Ecology B. Alan R. Liss, New York, USA, pp. 387-439. 